Volume 2 Issue 2, July-December 2021: pp. 85-94.

Indonesian Private Law Review.

Fakultas Hukum, Universitas Lampung,

Bandar Lampung, Indonesia.

P-ISSN: 2723-259X E-ISSN: 2745-9284

https://jurnal.fh.unila.ac.id/index.php/iplr

\title{
THE POLICY MODEL OF DIGITAL-BASED MICRO-BUSINESS ASSISTANCE FOR ECONOMIC RECOVERY DURING THE PANDEMIC
}

\author{
Lukmanul Hakim \\ Universitas Bandar Lampung, Indonesia \\ lukman517422@gmail.com
}

Submitted: February 9, 2021; Reviewed: June 25, 2021; Accepted: June 28, 2021

DOI: 10.25041/iplr.v2i2.2312

\begin{abstract}
Micro-businesses have an essential role in driving an economic revival in Indonesia. However, they are particularly vulnerable during the pandemic. The COVID-19 pandemic has significantly impacted the long-term viability of micro, small, and medium-sized enterprises (MSMEs) in the financing, production, distribution, and market demand. This paper argues that an assistance policy model for micro-businesses accelerating the economy during a pandemic is needed. It also raises the question of how government policies in developing micro-businesses. The library method, which relied on secondary data, was used to conduct the research. The result suggests that the ideal assistance model policy for MSMEs in accelerating the regional economy is by using platform-based digital technology so that the flexibility of purchasing raw materials to sales can be integrated into one and reach all consumers around the world. Government policies in developing MSMEs in the new normal era include launching the National Economic Recovery Program, as mandated by Government Regulation Number 23 of 2020, implementing stimulus programs for MSMEs such as interest subsidies and restructuring.
\end{abstract}

Keywords: Digital Based, Mentoring Model, Micro Business, Policy.

\section{A. Introduction}

Micro-businesses are very flexible, self-contained business units run by individuals and businesses. ${ }^{1}$ As the central pillar of the national economy, microbusinesses are the backbone of the country's recovery, even in times of crisis, and thus cannot be separated from the Indonesian economy. The development of micro-enterprises in developing countries is hampered by several factors, including limited capital, difficulties in product marketing, and distribution of other raw material procurement products. ${ }^{2}$ In addition, the lack of human resources in accessing technology and information still has many shortcomings and limitations both in the traditional and modern sectors. Another factor is the unclear and uncertain direction of business legality. ${ }^{3}$

\footnotetext{
${ }^{1}$ Tulus Tambunan, Usaha Mikro Kecil Dan Menengah Di Indonesia (Jakarta: LP3ES, 2012):11.

${ }^{2}$ Azhar Affandi et al., "Optimization of MSMEs Empowerment in Facing Competition in the Global Market during the COVID-19 Pandemic Time," Systematic Reviews in Pharmacy 11, no. 11 (2020): 1510, https://doi.org/10.31838/srp.2020.11.213.

${ }^{3}$ Pradnya Paramita Hapsari, Abdul Hakim, and Saleh Soeaidy, "Pengaruh Pertumbuhan Usaha Kecil Menengah (UKM) Terhadap Pertumbuhan Ekonomi Daerah (Studi Di Pemerintah Kota Batu)," Jurnal Wacana 17, no. 2 (2014): 88-92.
} 
Micro-businesses are defined on Law Number 20 of 2008 concerning Micro, Small and Medium Enterprises (MSMEs). Small Business is a productive economic business that operates independently and is carried out by individuals or business entities that are not subsidiaries or that are not subsidiaries that are owned, controlled, or become part of, either directly or indirectly, a medium or large business that meets the criteria for a small business as defined by the law. Medium-sized businesses are stand-alone productive economic businesses carried out by individuals or business entities that are not subsidiaries or branches of companies that are owned, controlled, or become a part of either directly or indirectly with Small Businesses or Large Businesses with total net assets or annual sales results as defined by law. According to MSME Empowerment Law No. 20 of 2008, the goal of MSME Empowerment is to:

1. Achieve a balanced, developing, and just national economic structure;

2. Grow and develop MSMEs' ability to become a solid and self-sufficient business; and

3. Increasing the role of micro, small, and medium-sized enterprises (MSMEs) in regional development, job creation, income distribution, economic growth, and poverty alleviation.

Nowadays, micro-businesses are one of the pillars of driving the economy in Indonesia. The number of MSMEs in Indonesia is quite large, making business opportunities in Indonesia even better. In 2020, it was estimated that there would be more than 65 million MSME players throughout Indonesia. ${ }^{4}$ Micro-businesses have an essential role in the economic space of the community, which makes micro-businesses a driver of economic revival in Indonesia. The flexibility possessed by micro-businesses did not make business actors affected by the crisis in 1998 and 2008. This condition did not apply in the first quarter of 2020, which caused a decline in micro-businesses due to the Covid-19 pandemic. Based on the Indonesian Chamber of Commerce and Industry or Kamar Dagang dan Industri Indonesia (Kadin) data, almost 80\% of micro-businesses have gone out of business due to COVID-19. In the last few months, microentrepreneurs have made many attempts to rise amid a pandemic in a new normal era.

The contribution of micro-businesses to GDP is quite significant in Indonesia based on statistical data where micro-businesses dominate the business sector from other businesses such as small, medium or even large businesses. Micro-enterprises in various industrial sectors play an important role considering the criteria are very flexible and non-formal. Based on data from the Ministry of Cooperatives and Small and Medium Enterprises, in 2018, almost 64 million micro-businesses consisted of fashion, education, technology, and other sectors. ${ }^{5}$ The existence of the Covid-19 pandemic has had an impact on micro business actors. ${ }^{6}$ Since May 2020, more than 185,184 MSME actors were affected by Covid $-19,{ }^{7}$ most of whom were affected by the food and beverage sector. ${ }^{8}$ In efforts to overcome micro-business problems, especially in the new normal era, mentoring is one of the most effective and efficient efforts and programs to overcome the problems at hand. Through the mentoring process, it is hoped to print and grow micro-businesses to continue to rise in adversity after the COVID-19 pandemic.

\footnotetext{
${ }^{4}$ Ahmad Ulil Albab Al Umar et al., "The Economic Impact of the Covid-19 Outbreak : Evidence from Indonesia," Jurnal Inovasi Ekonomi 5, no. 3 (2020): 71-76, https://doi.org/10.22219/jiko.v5i3.11889.

${ }^{5}$ Kementerian Koperasi dan UKM RI, "Perkembangan Data Usaha Mikro, Kecil, Menengah (UMKM) Dan Usaha Besar (UB)," Kementerian Koperasi dan UKM, 2018, https://www.kemenkopukm.go.id/data-umkm.

${ }^{6}$ Noor Fzlinda Fabeil and Juliana Pazim, Khairul Hanim Langgat, "The Impact of COVID-19 Pandemic Crisis on Micro-Enterprises: Entrepreneurs' Perspective on Business Continuity and Recovery Strategy," Journal of Economics and Business 3, no. 2 (2020): 838, https://doi.org/10.31014/aior.1992.03.02.241.

7 Herman, "2.322 Koperasi Dan 185.184 UMKM Terdampak Covid-19," Berita Satu, 2020, https://www.beritasatu.com/ekonomi/642537/2322-koperasi-dan-185184-umkm-terdampak-covid19.

${ }^{8}$ Deden Sutisna, Fizi Fauziya, and Rino Nikki Pranoto, "Employee Engagement of Small and Medium Micro Businesses (MSME) in Bandung City - West Java: At the Condition of Covid Pandemic 19," PalArch's Journal of Archaeology of Egypt / Egyptology 17, no. 4 (2020): 2845.
} 
The assistance that the government is currently developing through Ministry of Cooperatives and Small and Medium Enterprises is to form Pusat Layanan Usaha Terpadu Koperasi dan Usaha Mikro Kecil Menengah/ UMKM (PLUT - KUKM) or Integrated Business Service Center for Cooperatives and SMEs. The integrated business service centre is a means to answer the need for coordination, data synchronization, and acceleration of empowering MSMEs. Currently, there are 51 PLUTs scattered throughout the archipelago that provide economic growth in the regions to accelerate the economy in Indonesia in particular. The key to success in this proud national movement made in Indonesia is cooperation to increase sales of micro-goods and services by utilizing information technology so that micro-businesses can prepare themselves to go global and go online so that micro-businesses can continue to rise positively. Given that currently, the role of the digital world is vital, especially in marketing tools that has an impact on offline sales activities. ${ }^{9}$ Easy infrastructure access and digitization in this new normal era assist micro-businesses. It also continues to implement a health protocol system so that access to offline sales, which was previously limited due to social/physical distancing, can now rise again in this era - this new normal. Assistance patterns and policies in each region can be synergized to make micro-businesses continue to rise amidst the downturn affected by Covid-19. ${ }^{10}$

Based on the above background, the formulation of a mentoring model policy for microbusinesses in the context of economic acceleration during the pandemic is an effort to boost the economy in each region as a means and factor driving the regional economy and the national economy in this new normal era. The impact that occurs due to corona has several effects for micro-business actors, ${ }^{11}$ including marketing, demand and raw materials. However, the problems that occurred in MSMEs in 1998 and 2008 were very different from 2020, which was due to the Covid-19 pandemic. In addition, other legal problems that arise are problems of accounts payable and employment. ${ }^{12}$

The discussion above is related to this study's main problems, which were developed based on the following questions: What are the Government Policies in developing micro-businesses during a pandemic? And what is the ideal assistance policy model for micro-businesses in accelerating the economy during a pandemic? The research method used in this research is to use the library method by using the type of data in secondary data. ${ }^{13}$ This secondary data consists of primary legal materials, secondary legal materials and tertiary legal materials as follows:

1. Primary Legal Materials, namely, legal materials whose contents have binding power to the community originating from agreements and laws. Primary legal materials used in this research are:

a. Law Number 25 of 2007 concerning Investment;

b. Law Number 20 of 2008 concerning Micro, Small and Medium Enterprises;

c. Government Regulation Number 23 of 2020 concerning Implementation of the National Economic Recovery Program in Support of State Financial Policy for Handling the Corona Pandemic and/or Facing Threats That Endanger the National Economy and/or Financial Stability and Save the National Economy;

\footnotetext{
${ }^{9}$ Fatimah and Darna, "Peranan Koperasi Dalam Mendukung Permodalan Usaha Kecil Dan Mikro (UKM)," Jurnal Ekonomi Dan Bisnis 10, no. 2 (2011): 127-38, https://doi.org/10.32722/eb.v10i2.431.

${ }^{10}$ Sigit Irianto, Widyarini Indriasti Wardani, and Aniek Tyaswati Wiji Lestari, "Harmonizing Rules Micro Small and Medium Enterprises in the Era of the Pandemic Covid19 in Indonesia," European Journal of Molecular \& Clinical Medicine 7, no. 11 (20AD): 650.

${ }^{11}$ Pravakar Sahoo and Ashwani, "COVID-19 and Indian Economy: Impact on Growth, Manufacturing, Trade and MSME Sector,” Global Business Review 21, no. 5 (2020): 1159, https://doi.org/10.1177/0972150920945687.

${ }^{12}$ Hadi Ismanto and Tohir Diman, "Analisis Efektivitas Pemberian Pinjaman Program Pembiayaan UMKM Oleh Koperasi,” Jurnal Economia 10, no. 2 (2014): 148-64, https://doi.org/10.21831/economia.v10i2.7541.

${ }^{13}$ Soerjono Soekanto, Pengantar Penelitian Hukum, 8th ed. (Jakarta: UI-Press, 2018): 10-13.
} 
2. Secondary Legal Materials, namely legal materials containing explanations of primary legal materials. Secondary legal materials used in this research are journals, papers and the internet related to the problem.

3. Tertiary Legal Materials, namely legal materials containing instructions and explanations for primary and secondary legal materials such as large Indonesian dictionaries, legal dictionaries and encyclopedias.

The data processing and analysis method used by the author is by using qualitative methods. However, in this presentation, quantitative data is also used to support the analysis, particularly data regarding existing regional regulations regarding the licensing sector. With the qualitative method, the quality and validity of the data from the secondary data used are prioritized and not the amount or quantity. This qualitative method will produce descriptive-analytical data that what is stated by the research objectives concerned will be stated in writing or verbally and natural behavior.

\section{B. Discussion}

Previous research titled Food MSME Assistance Model through Higher Education Business Incubators in 2014 suggested that Business Incubators in Indonesia had not developed. This was due to the lack of government support in the concept of the incubation model. Business in mentoring the food MSME sector. ${ }^{14}$ According to research entitled The Role of the Government in fostering SMEs in Enrekang Regency in 2017, it was explained that besides becoming a facilitator in mentoring, funding, capital and training, the role of the government is also as a regulator in making and implementing policies and regulatory models related to the development and assistance of MSMEs. ${ }^{15}$ Furthermore, one of the implications of the concept of Usaha Mikro Kecil Menengah (UMKM) is one of the strategic efforts in empowering the community's economy. The program that has been implemented is still felt to be unable to provide benefits to assistants and MSMEs in development because companion development is still a project that does not yet have a companion development model. ${ }^{16}$

In this study, the researcher describes an original follow-up study titled the formulation of an assistance policy model for micro-businesses in the context of accelerating the economy during the pandemic in 2020, in which the researcher argues the importance of a companion policy model for micro-businesses during the pandemic. They were starting a mentoring pattern by the government in 2017 to re-record all existing micro-business actors. By entering technology and industrial revolution 4.0 eras in 2018, UMKM was led to the digital era of technology. The government proclaimed the ideals as a step to upgrade micro businesses. Therefore, the marketing of products that were initially based only offline will switch to online so that the market share of micro-business products will be more open and worldwide.

Through the Ministry of Cooperatives and SMEs, the government provides a mentoring scheme and several stimulus programs for MSMEs to continue to progress and rise amid the downturn of micro-businesses in this new normal era. One of the mentoring patterns currently being prepared is the Foster Brother scheme in collaboration between the Ministry of Cooperatives, UKM, and Lazada. This foster brother and sister model scheme is one of the patterns of mentoring and business development by foster siblings who come from business

\footnotetext{
${ }^{14}$ Rokhani Hasbullah et al., "Model Pendampingan UMKM Pangan Melalui Inkubator Bisnis Perguruan Tinggi," Jurnal Ilmu Pertanian Indonesia (JIPI) 19, no. 1 (2014): 43-49.

15 Devi Chandra Nirwana, Muhammadiah, and Muhajirah Hasanuddin, "Peran Pemerintah Dalam Pembinaan Usaha Kecil Menengah Di Kabupaten Enrekang,” Kolaborasi: Jurnal Administrasi Publik 3, no. 1 (2017): 13, https://doi.org/10.26618/kjap.v3i1.890.

16 Novitri Landong Namora Sihombing and Raden Hasan, “Analisa Kinerja Pendamping Usaha Mikro Kecil Menengah Kota Tangerang Selatan Terhadap Kemajuan UMKM," JIM UPB 7, no. 2 (2019): 8, https://doi.org/10.33884/jimupb.v7i2.1221.
} 
actors and the community who participate in helping increase the capacity of their foster siblings. ${ }^{17}$

The Foster Brother program is considered positive because it can foster a spirit of cooperation where prominent business actors can help small business actors and also make a positive contribution to business actors who become foster siblings. After all, with this program, it is expected that business actors who initially sells offline can be upgraded to online. With Go-digital, Go-modern is expected to be able to penetrate Go-global with foreign coverage. Other assistance programs include contributing to the acceleration of the economy in the regions. Because each region has different policies and regulations in tackling microbusinesses, they continue to rise in business development during the new normal era. The assistance program must be able to make a positive contribution because reviving microbusinesses is currently in a fairly slow stage because there are still many behaviors. Consumers still do not believe in domestically-made products. These factors increase the level of microbusinesses that have not been running significantly even though many campaigns are proud of being made in Indonesia. However, there are still many people who do not understand why micro businesses should be. ${ }^{18}$

Based on data from micro-businesses that have Go-Online, nearly 9 million microbusinesses have entered the digital era. Therefore, it seems that the digitalization of microbusinesses must be realized immediately so that all micro-businesses in Indonesia can evenly be upgraded to face the new normal era of the COVID-19 pandemic. Several things underlie digitization in the new normal pandemic era in this new normal era, including the following:

1. MSME Operational Activities must continue to apply health protocols;

2. The use of digital-based financial transactions;

3. Marketing and marketing activities with an online system to comply with social distancing / physical distancing rules.

Regarding Go-Digital MSMEs where there are three solutions provided in the banking sector, including the following:

1. Digital Banking as a transaction tool;

2. Online Marketing as a marketing tool;

3. Providing CSR funds for MSMEs.

The steps and strategies in the mentoring pattern to develop MSMEs in the new normal era hope that banks will be able to help digitize MSMEs so that they are ready to compete again in this new normal era. Because when MSMEs can continue to exist and be strong in the new normal era, it is hoped that MSMEs can appear to be saviors and buffers of the national economy amid the crisis due to the Covid-19 pandemic.

\section{MSME Assistance During the New Normal Era changed from Offline to Online}

The COVID-19 pandemic has made a new change in the way the business world operates, considering that at first, limiting physical access or social access was a new trend for the digital world. What started as an offline sales activity in a shop or kiosk has now changed into a marketplace and web-based era. However, not all regions take advantage of this digital platform, especially in underdeveloped areas that are still untouched by the internet, so there must still be a push towards Go-Online. This new normal era condition encourages the government through related institutions and BUMN to reach digital access to all remote areas.

\footnotetext{
17 I Wayan Dipta, "Strategi Penguatan Usaha Mikro, Kecil, Dan Menengah (UMKM) Melalui Kerjasama Kemitraan Pola," Jurnal INFOKOP 16 (2008): 62-75.

18 Jiři Koleňák, "Reinforcement of Succes of Strategic Alliance of Small and Medium Enterprises in Chez Republik," Journal of Vadya Management 3-4, no. 12-13 (2006): 45-57.
} 
No exception with connectivity, which must ensure the smooth change of the online market for micro-businesses in the regions. ${ }^{19}$

Digital equity in underdeveloped areas does take time considering infrastructure development so that connectivity becomes smooth depending on the facilities and infrastructure built and the government's participation in mentoring, training and development programs for digital-based micro businesses. Indonesia was at the beginning of a pandemic where online commerce was growing very fast. Online sales platforms had the flexibility and freedom to compare. Both brands, prices, and online sales grew very significantly.

The assistance of micro-businesses in the new normal era was further mobilized by the Ministry of Cooperatives and SMEs through SMESCO as part of the Ministry of CooperativesUKM to support government programs in restoring the economic conditions of the economy in the new normal era. ${ }^{20}$ Several programs from SMESCO aim to assist micro-businesses to be more effective and efficient, so that digital access is equal to all micro-businesses in Indonesia.

\section{Government Policy in Developing Micro-Businesses During Pandemic}

The pandemic of covid-19 has had a massive impact on society and business actors. In this case, the pandemic is detrimental to global and national economic growth. During the new normal era, the government took some policy and strategic steps in programs ranging from social assistance to revolving funds. ${ }^{21}$ In the new normal period, several government policies are specifically for increasing micro-businesses to return to their enthusiasm and rise from the downturn after the Covid-19 pandemic. Given that micro-businesses are one of the drivers of the national economy, there is a need for a strategy and government policy in fostering and developing the economy for micro-businesses so that micro-businesses affected by Covid-19 can again increase their business capacity.

Another contribution from several policies by the government is to boost people's purchasing power. This boost is performed by motivating Indonesian society always to buy local products and increase domestic purchasing power. Therefore, the economy and microbusinesses continue to operate as usual, improving the regional economy and supporting an increase in GDP National. Government policies to support the development of microbusinesses include launching the National Economic Recovery program as mandated in Government Regulation Number 23 of 2020. In addition, a budget of nearly 123T was rolled out to increase the micro-business stimulus with interest subsidies, restructuring, and guarantees for working capital. The government is a policy-maker stakeholder with all the authority and potential to encourage bank and non-bank financial institutions to jointly provide capital injections for micro-enterprises with easier terms and conditions.

Seeing the ability of micro-businesses that can return loan principal to loan sharks with higher interest is an opportunity for financial institutions to provide assistance and guidance for micro-businesses because micro-enterprises are one of the non-formal business sectors that have flexible business characteristics. Assisting financial institutions and business activities can again contribute to economic growth by providing employment and increasing purchasing power. In this study, the current development policy for micro-enterprises is the importance of business management, especially in production, distribution and offline sales. So that government policy will be more appropriate if it includes elements of business management or business assistance for micro-enterprises. Furthermore, with integrated and digital data-based

\footnotetext{
19 Lukmanul Hakim et al., "Legal Aspects of Micro Business Development Institutions in State Purpose of Welfare,” Fiat Justisia 14, no. 3 (2020): 247-60, https://doi.org/10.25041/fiatjustisia.v14no3.1804.

${ }^{20}$ Ramadhan, "Strategi Pemulihan UMKM Di Masa New Normal," Asumsi, 2020.

${ }^{21}$ Adi Trisnojuwono, Aida Vitayala S. Hubeis, and Eko Ruddy Cahyadi, "Analisis Strategi Pembiayaan Usaha Mikro Dan Kecil Melalui Dana Bergulir Pada Lembaga Pengelola Dana Bergulir," Manajemen IKM 12, no. 2 (2017): 178-86, https://doi.org/http://journal.ipb.ac.id/index.php/jurnalmpi/.
} 
business management, the sales will be wider in one area and reach all cities/regencies and other provinces with national or even worldwide coverage. Optimizing online platforms such as marketplaces can play a more active role in the current new normal era.

3. The Ideal Mentoring Model Policy Needs to be Carried Out For Micro-Businesses in The Context Of Accelerating The Economy During Pandemic.

Microenterprises play an important role in Indonesia's economy. The role as a driving force for the economy means micro-businesses can increase income and employment. They are very supportive and have the most strategic sector throughout the archipelago in Indonesia's economic development. Therefore, assistance so that micro businesses continue to develop is always the concern of many parties, such as the government, legislature, central bank, banking, the private sector, and other institutions related to micro-business development.

Although micro-businesses have various advantages, micro-businesses also have many weaknesses and often face problems from classic problems such as capital and other problems. In addition, the new problems due to the COVID-19 pandemic that emerged in the first quarter of 2020 had a large enough impact on micro-businesses throughout the archipelago so that micro-businesses in some regions were unable to return to running their business. Based on data from KADIN 2020, almost $80 \%$ of micro-businesses in Indonesia have experienced a significant impact due to Covid-19 and its limited social interactions. Micro-entrepreneurs have limitations in offline sales. As a result, micro-entrepreneurs have to close their businesses for some time and even because they cannot sustain the business of business actors until they go bankrupt because they cannot close all their business activities.

The government has provided several stimuli. Program packages such as restructuring and provision of interest subsidies to deferral of principal payments have greatly helped micro business actors to rise again in the new normal era after the pandemic hit globally in the world and Indonesia. The government appears to view micro-business problems as more of a social problem than a business problem, based on past experience. The government values excessive protection or provision of facilities so that policies for micro-businesses provided by the government do not emphasize market approaches to face business competition, as an example, in today's pandemic era. Therefore, it is possible to create a pattern of assistance policies for ideal micro-businesses such as in the digital-based business management sector or digital marketing so that micro-business actors affected by Covid-19 can return.

The ideal assistance model policy for micro-businesses in accelerating the regional economy in the new normal era is to create a unique digital-based platform with integrated business management starting from the production process, such as stock of raw materials and supporting stock to process. Online production and sales through a marketplace platform provide a special space for micro-entrepreneurs to reach consumers in the micro-business area itself and reach other regions and across countries.

The business assistance model, which was originally offline to online, provides sufficient flexibility to increase the competitiveness of micro-businesses and people's purchasing power in the new normal era in particular. The role of the digital marketing world provides a very important role considering that micro-businesses are characteristic that is flexible and able to adapt to all kinds of circumstances. In the new normal era, online activities can foster a sales spirit for micro-businesses and increase people's consumption power. Moreover, online activities are not fixated by social restrictions because online flexibility reaches a fairly wide coverage. Of course, this gives a positive impression for all levels of society and can become economic support and increase GDP in their respective regions. 


\section{Conclusion}

The main conclusion that can be drawn is that the ideal assistance model policy for MSMEs in accelerating the regional economy is by using platform-based digital technology so that the flexibility of purchasing raw materials to sales can be integrated into one and reach all consumers. Broadly translated, our findings indicate that government policies in developing MSMEs in the new normal era that have been implemented are stimulus programs such as interest subsidies and restructuring for MSMEs. The conclusion of what has previously been discussed and some suggestions regarding this study are as follows:

1. To the Government to find the right and ideal digital platform alternatives with the characteristics of MSMEs,

2. To the community to always use local and proud products made in Indonesia by cooperation to maintain domestic consumption so that economic recovery can accelerate, and

3. For MSMEs to continuously adapt amid a pandemic by using all the programs that have been prepared.

\section{BIBLIOGRAPHY}

Affandi, Azhar, Sarwani, Akhmad Sobarna, Heri Erlangga, Ade Onny Siagian, Agus Purwanto, Aidil Amin Effendy, et al. "Optimization of MSMEs Empowerment in Facing Competition in the Global Market during the COVID-19 Pandemic Time." Systematic Reviews in Pharmacy 11, no. 11 (2020): 1510. https://doi.org/10.31838/srp.2020.11.213.

Albab Al Umar, Ahmad Ulil, Herninda Pitaloka, Eka Resmi Hartati, and Dessy Fitria. "The Economic Impact of the Covid-19 Outbreak : Evidence from Indonesia." Jurnal Inovasi Ekonomi 5, no. 3 (2020): 71-76. https://doi.org/10.22219/jiko.v5i3.11889.

Dipta, I Wayan. "Strategi Penguatan Usaha Mikro, Kecil, Dan Menengah (UMKM) Melalui Kerjasama Kemitraan Pola." Jurnal INFOKOP 16 (2008): 62-75.

Fabeil, Noor Fzlinda, and Juliana Pazim, Khairul Hanim Langgat. "The Impact of COVID-19 Pandemic Crisis on Micro-Enterprises: Entrepreneurs' Perspective on Business Continuity and Recovery Strategy." Journal of Economics and Business 3, no. 2 (2020): 838. https://doi.org/10.31014/aior.1992.03.02.241.

Fatimah, and Darna. "Peranan Koperasi Dalam Mendukung Permodalan Usaha Kecil Dan Mikro (UKM)." Jurnal Ekonomi Dan Bisnis 10, no. 2 (2011): 127-38. https://doi.org/10.32722/eb.v10i2.431.

Hakim, Lukmanul, Etty Mulyati, Djuhaendah Hasan, and Tarsisius Murwadji. "Legal Aspects of Micro Business Development Institutions in State Purpose of Welfare." Fiat Justisia 14, no. 3 (2020): 247-60. https://doi.org/10.25041/fiatjustisia.v14no3.1804.

Hapsari, Pradnya Paramita, Abdul Hakim, and Saleh Soeaidy. "Pengaruh Pertumbuhan Usaha Kecil Menengah (UKM) Terhadap Pertumbuhan Ekonomi Daerah (Studi Di Pemerintah Kota Batu)." Jurnal Wacana 17, no. 2 (2014): 88-92.

Hasbullah, Rokhani, Memen Surahman, Ahmad Yani, Deva Primadia Almada, and Elisa Nur Faizaty. "Model Pendampingan UMKM Pangan Melalui Inkubator Bisnis Perguruan Tinggi." Jurnal Ilmu Pertanian Indonesia (JIPI) 19, no. 1 (2014): 43-49.

Herman. "2.322 Koperasi Dan 185.184 UMKM Terdampak Covid-19." Berita Satu, 2020. https://www.beritasatu.com/ekonomi/642537/2322-koperasi-dan-185184-umkmterdampak-covid19. 
Irianto, Sigit, Widyarini Indriasti Wardani, and Aniek Tyaswati Wiji Lestari. "Harmonizing Rules Micro Small and Medium Enterprises in the Era of the Pandemic Covid19 in Indonesia." European Journal of Molecular \& Clinical Medicine 7, no. 11 (20AD): 650.

Ismanto, Hadi, and Tohir Diman. "Analisis Efektivitas Pemberian Pinjaman Program Pembiayaan UMKM Oleh Koperasi." Jurnal Economia 10, no. 2 (2014): 148-64. https://doi.org/10.21831/economia.v10i2.7541.

Koleňák, Jiří. "Reinforcement of Succes of Strategic Alliance of Small and Medium Enterprises in Chez Republik." Journal of Vadya Management 3-4, no. 12-13 (2006): 45-57.

Nirwana, Devi Chandra, Muhammadiah, and Muhajirah Hasanuddin. "Peran Pemerintah Dalam Pembinaan Usaha Kecil Menengah Di Kabupaten Enrekang." Kolaborasi: Jurnal Administrasi Publik 3, no. 1 (2017): 13. https://doi.org/10.26618/kjap.v3i1.890.

Ramadhan. "Strategi Pemulihan UMKM Di Masa New Normal.” Asumsi, 2020.

RI, Kementerian Koperasi dan UKM. "Perkembangan Data Usaha Mikro, Kecil, Menengah (UMKM) Dan Usaha Besar (UB)." Kementerian Koperasi dan UKM, 2018. https://www.kemenkopukm.go.id/data-umkm.

Sahoo, Pravakar, and Ashwani. "COVID-19 and Indian Economy: Impact on Growth, Manufacturing, Trade and MSME Sector.” Global Business Review 21, no. 5 (2020): 1159. https://doi.org/10.1177/0972150920945687.

Sihombing, Novitri Landong Namora, and Raden Hasan. “Analisa Kinerja Pendamping Usaha Mikro Kecil Menengah Kota Tangerang Selatan Terhadap Kemajuan UMKM.” JIM UPB 7, no. 2 (2019): 8. https://doi.org/10.33884/jimupb.v7i2.1221.

Soekanto, Soerjono. Pengantar Penelitian Hukum. 8th ed. Jakarta: UI-Press, 2018.

Sutisna, Deden, Fizi Fauziya, and Rino Nikki Pranoto. "Employee Engagement of Small and Medium Micro Businesses (MSME) in Bandung City - West Java: At the Condition of Covid Pandemic 19." PalArch's Journal of Archaeology of Egypt / Egyptology 17, no. 4 (2020): 2845.

Trisnojuwono, Adi, Aida Vitayala S. Hubeis, and Eko Ruddy Cahyadi. "Analisis Strategi Pembiayaan Usaha Mikro Dan Kecil Melalui Dana Bergulir Pada Lembaga Pengelola Dana Bergulir." Manajemen IKM 12, no. 2 (2017): 178-86. https://doi.org/http://journal.ipb.ac.id/index.php/jurnalmpi/.

Tulus Tambunan. Usaha Mikro Kecil Dan Menengah Di Indonesia. Jakarta: LP3ES, 2012. 
